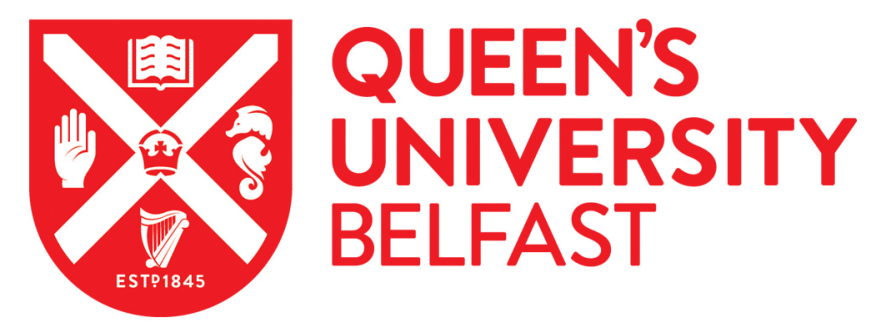

\title{
An experimental and numerical study on the crush behaviour of hybrid unidirectional/woven carbon-fibre reinforced composite laminates
}

Liu, H., Falzon, B., \& Dear, J. (2019). An experimental and numerical study on the crush behaviour of hybrid unidirectional/woven carbon-fibre reinforced composite laminates. International Journal of Mechanical Sciences. https://doi.org/10.1016/j.jijmecsci.2019.105160

Published in:

International Journal of Mechanical Sciences

Document Version:

Peer reviewed version

Queen's University Belfast - Research Portal:

Link to publication record in Queen's University Belfast Research Portal

Publisher rights

Copyright 2019 Elsevier

This manuscript is distributed under a Creative Commons Attribution-NonCommercial-NoDerivs License

(https://creativecommons.org/licenses/by-nc-nd/4.0/), which permits distribution and reproduction for non-commercial purposes, provided the author and source are cited.

\section{General rights}

Copyright for the publications made accessible via the Queen's University Belfast Research Portal is retained by the author(s) and / or other copyright owners and it is a condition of accessing these publications that users recognise and abide by the legal requirements associated with these rights.

Take down policy

The Research Portal is Queen's institutional repository that provides access to Queen's research output. Every effort has been made to ensure that content in the Research Portal does not infringe any person's rights, or applicable UK laws. If you discover content in the Research Portal that you believe breaches copyright or violates any law, please contact openaccess@qub.ac.uk. 


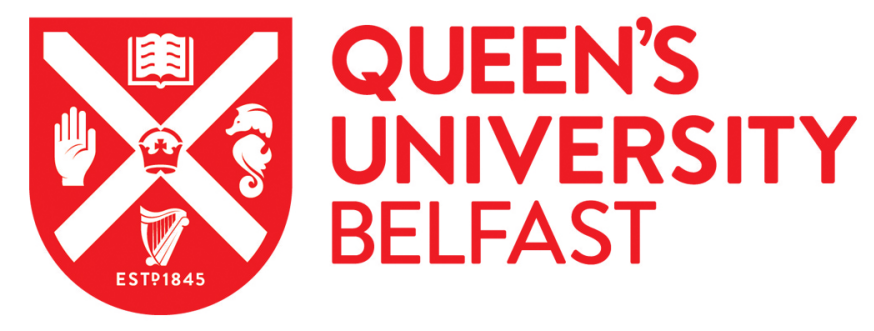

\section{An experimental and numerical study on the crush behaviour of hybrid unidirectional/woven carbon-fibre reinforced composite laminates}

Falzon, B., Liu, H., \& Dear, J. (2019). An experimental and numerical study on the crush behaviour of hybrid unidirectional/woven carbon-fibre reinforced composite laminates. International Journal of Mechanical Sciences.

Published in:

International Journal of Mechanical Sciences

Document Version:

Peer reviewed version

Queen's University Belfast - Research Portal:

Link to publication record in Queen's University Belfast Research Portal

\section{General rights}

Copyright for the publications made accessible via the Queen's University Belfast Research Portal is retained by the author(s) and / or other copyright owners and it is a condition of accessing these publications that users recognise and abide by the legal requirements associated with these rights.

Take down policy

The Research Portal is Queen's institutional repository that provides access to Queen's research output. Every effort has been made to ensure that content in the Research Portal does not infringe any person's rights, or applicable UK laws. If you discover content in the Research Portal that you believe breaches copyright or violates any law, please contact openaccess@qub.ac.uk. 


\title{
An experimental and numerical study on the crush behaviour of hybrid unidirectional/woven carbon-fibre reinforced composite laminates
}

\author{
Haibao Liu ${ }^{a}$, Brian G. Falzon ${ }^{\text {b* }}$, John P. Dear ${ }^{a}$ \\ ${ }^{a}$ Department of Mechanical Engineering, Imperial College London, South Kensington Campus, London SW7 2AZ, UK \\ ${ }^{b}$ Advanced Composites Research Group, School of Mechanical and Aerospace Engineering, Queen's University Belfast, \\ Ashby Building, Belfast BT9 5AH, UK
}

Email: haibao.liu@imperial.ac.uk, b.falzon@qub.ac.uk, j.dear@imperial.ac.uk

Corresponding author: Prof Brian G. Falzon +44 (0) 7450893313

\begin{abstract}
In composite aircraft structures, woven carbon-fibre reinforced plies are often used as the surface plies of a monolithic composite panel, made from unidirectional plies, to mitigate damage during drilling and provide a measure of impact damage resistance. This research presents, for the first time, a detailed experimental and numerical study on the crush behaviour of hybrid unidirectional/woven carbon-fibre reinforced composite laminates. Quasi-static crush tests are performed on composite specimens with two different trigger geometries; a bevel-trigger and a steeple-trigger. A computational model, which accounts for both interlaminar and intralaminar damage in hybrid unidirectional (UD)/woven composite laminates, implemented as a user subroutine in Abaqus/Explicit, was used. A comparison between experimental and numerical results confirms the computational tool's accuracy in predicting the energy absorption and damage mechanisms of hybrid specimens. The proposed approach could significantly reduce the extent of physical testing required in the development of crashworthy structures.
\end{abstract}

Key words: Hybrid composites, Fracture, Damage mechanics, Finite Element Analysis (FEA). 


\section{Introduction}

Composite materials now dominate the structure of the latest wide-body twin-engine passenger aircraft and are making increasing inroads into smaller narrow-bodies such as the Bombardier CSeries/Airbus A220. Composite airframe production still requires the assembly of sub-sections using mechanical fasteners which, in turn, necessitates drilling. Laminates made from unidirectional plies, to meet structural requirements, are vulnerable to surface damage during drilling. A hybrid composite laminate, which uses woven surface plies, but maintains unidirectional inner plies, was developed by industry, to mitigate this form of damage. A hybrid composite laminate has been successfully employed on the $\mathrm{A} 220$ passenger aircraft wing, produced using a patented manufacturing process referred to as Resin Transfer Infusion. To date, the mechanical behaviour of this hybrid composite laminate, specifically the energy absorption and crush performance, has not been adequately investigated. This may be due to the extent of physical testing required, in the absence of robust, accurate numerical models, which is costly and time-consuming [1,2]. Deployment of this material in the fuselage necessitates such considerations at a time when the FAA is re-examining its crashworthiness requirements as applied to non-metallic materials. Consequently. the development of computational models for predicting the response of hybrid composite laminates under crushing loading is much desired, extending the current state-of-the-art which has focused on the modelling of non-woven composites as outlined below.

Xiao [3] proposed a damage model based on the Matzenmiller-Lubliner-Taylor (MLT) model, a continuum damage mechanics (CDM) based model, to evaluate the energy absorption of composite structures for crashworthiness assessments. This model accounted for unloading and reloading which the authors claimed improved the dynamic explicit simulation, using LS-DYNA [4], as well as the accuracy of the simulation. An experimental and numerical study was carried out by Joosten et al. [5] to investigate the quasi-static crushing response of carbon epoxy composite hat-shaped crush elements. Specimens with a steeple-type triggering mechanism were tested to obtain experimental data for model validation. The proposed damage model yielded reasonable agreement with the load versus displacement behaviour observed during experiments. Tan and Falzon [6] developed a mesoscale composite damage model, which included nonlinear shear constitutive laws, and a range 
of novel techniques to capture accurately the material response under crushing. Good qualitative and quantitative agreement was achieved between experimental and numerical results.

In this paper, an efficient and reliable physical testing method was used to conduct the crush tests, where simple crush specimens with two different trigger geometries were tested to investigate the crush behaviour of hybrid UD/woven composite laminates and validate the numerical model [8]. The loaddisplacement response, energy absorption and damage morphology obtained from the numerical simulation were compared with the results obtained from the physical crush tests. In addition, a modified high-fidelity predictive model was employed to simulate the crush event of hybrid composite laminates. Subsequently, a numerical comparison was conducted on the crushing response of hybrid UD/woven composites and UD-only composites. The fully validated computational model was then employed to conduct virtual crush tests with different friction coefficients between the composite and compression platen, to quantify the effects of contact friction on the crush response of composite laminates.

\section{Materials and methods}

\subsection{Sample preparation}

The material systems used in this study are IMS60 UD carbon fibre/epoxy and AS4 five harness satin (5HS) woven carbon fibre/epoxy laminated composites. The lay-up used in this research was [5HS/45/+45/90/0/-45/+45/90/+45/-45/90/+45/-45/0/90/+45/-45/5HS]. The UD and woven fabrics were stacked as shown in Fig. 1a, and pre-formed under a hot platen, Fig. $1 \mathrm{~b}$.

The preformed fabrics were subsequently used to manufacture the panels, from which the specimens were produced, using Resin Infusion under Flexible Tooling (RIFT) [9], Fig. 2. All panels were inspected using an ultrasonic scan system to ensure the specimens were free of any major defects. The basic mechanical properties required for data reduction were obtained using standard test methods [10-13].

The specimen geometry was based on a similar experimental study in [14]. The lay-up of each specimen was [5HS/-45/+45/90/0/-45/+45/90/+45/-45/90/+45/-45/0/90/+45/-45/5HS], and the two trigger geometries of these specimens are shown in Fig. 3. In the figure, the red arrow [14] indicates 
the longitudinal $\left(0^{\circ}\right)$ direction of the specimen, which is aligned with the crushing load direction. $t$ and $w$ are the sample thickness and sample width, respectively. $l_{c}$ is the length supported by the fixtures, and $l_{f}$ is the length of constant cross-section from the top of the fixtures. $l_{\alpha}$ and $l_{\beta}$ are the lengths of the bevel and steeple triggers, respectively. The specimens' dimensions are given in Table 1.

\subsection{Testing set-up}

For each specimen type, three samples were tested using a Hounsfield tensile testing machine with a $50 \mathrm{kN}$ load cell. The specimens were compressed between a compression platen and a lubricated surface joint, which can align the crushing samples to the crush loading direction. The load response was recorded directly from the load cell while the displacement was obtained from the instrumented moving crosshead. The testing speed was set at $1 \mathrm{~mm} / \mathrm{min}$, giving a nominal strain rate of approximately $1 \times 10^{-3} / \mathrm{s}$. The failure process in the crushing zone was recorded using a digital camera. A schematic and photo of the experimental set-up are shown in Figs, 4a and $4 \mathrm{~b}$, respectively.

\subsection{Data reduction}

During a crush event, the total energy absorbed by the specimen, $E_{C}$, is the integral of the load versus displacement curve,

$$
E_{C}=\int_{0}^{S} F d S,
$$

where $F$ is the crush load, and $S$ is the displacement of the compression platen. The specific energy absorption (SEA), which is a critical parameter of a structure`s crashworthiness, is defined as the energy absorbed per unit mass of material,

$$
S E A=\frac{E_{C}}{m},
$$

where $m$ is the mass of the material consumed over the crushing stroke or displacement $(S)$, and $E_{C}$ is the energy absorbed by the crush specimens [6].

\section{Damage model}

\subsection{Failure modes in composite laminates}


In the UD composite ply, the material response in the longitudinal direction is dominated by the fibres, whilst in the transverse and through-thickness direction, it is dominated by the matrix [15]. In the woven composite ply, fibres dominate both the longitudinal and transverse material response, and the matrix dominates the material response in the thorough-thickness direction. The main failure modes presented by UD and woven composites can be classified into two main categories: fibre-dominated damage and matrix-dominated damage.

Fig. 5a shows the fracture planes defined in the UD composite damage model. Plane U1, perpendicular to global direction 1 , is the longitudinal tension/compression fracture plane. Plane U2 and plane $\mathrm{U} 3$ refer to the transverse tension and transverse compression fracture planes, respectively. $\theta$ is the angle between plane $\mathrm{U} 3$ and transverse direction 2. For the woven composite damage model, damage is initiated on surfaces W1, W2 and W3, according to the Hashin-Rotem criteria [16]. These surfaces, which are perpendicular to global directions, 1, 2 and 3 respectively, are also used for damage evolution and energy dissipation, as shown in Fig. 5b.

\subsection{Damage initiation}

In this paper, the coordinate system 1-2-3 refers to the global coordinate system, and the coordinate system L-N-T refers to the local coordinate system, in which the fracture surface is located. The damage initiation criteria are shown in Table 2. In the developed model, Puck's criteria [17-19] and Hashin-Rotem [16] criteria were employed to capture the matrix-dominated damage in UD and woven composite plies, respectively.

In the above equations, $F_{f i b}^{T / C}$ are used to represent the failure indices for fibre-dominated tensile/compressive damage and $F_{m a t}^{T / C}$ are the failure indices for matrix-dominated tensile/compressive damage, in the unidirectional composite ply. In the model for woven composite ply, $F_{m a t}^{W 1}, F_{m a t}^{W 2}$ and $F_{m a t}^{W 3}$ are the failure indices for matrix-dominated damage on surfaces W1, W2 and W3 defined in the Hashin-Rotem criteria. $\varepsilon_{i j}$ and $\sigma_{i j}(i, j=1,2,3)$ are the current strains and stresses in the global coordinate system. $\sigma_{i j}^{O}(i, j=1,2,3)$ are the stresses corresponding to the damage initiation on surfaces $\mathrm{W} 1$ and $\mathrm{W} 2 . \sigma_{33}^{O T / O C}$ are the stresses corresponding to the tensile/compressive damage initiation on surface W3. The stresses, $\sigma_{N N}, \sigma_{N T}$ and $\sigma_{L N}$, are the current stresses on the fracture 
surface defined in Puck's criteria. Parameters $\lambda$ and $\kappa$ are defined by $\lambda=2 \mu_{L N} S_{23}^{A} / S_{12}^{A}-\kappa$, and $\kappa=$ $\left(S_{12}^{A}{ }^{2}-\left(Y_{T}\right)^{2}\right) / S_{23}^{A} Y_{T}[40]$, where $S_{12}^{A}$ and $S_{23}^{A}$ are the shear strengths. The transverse friction coefficients, $\mu_{N T}$ and $\mu_{L N}$, are based on Mohr-Coulomb theory where $\mu_{N T}=-1 / \tan \left(2 \theta_{f}\right), S_{23}^{A}=$ $Y_{C} / 2 \tan \left(\theta_{f}\right)$ and $\mu_{L N}=\mu_{N T} S_{12}^{A} / S_{23}^{A}, Y_{T}$ and $Y_{C}$ are the transverse tensile strength and transverse compressive strength, respectively.

\subsection{Damage propagation}

In the developed damage model, the strains in a UD composite ply, acting on the fracture plane defined by Puck's criteria, were combined as the $l^{2}$-norms of strain vectors [20]. Likewise, in the woven ply, the combined strains, acting on surfaces W1, W2 and W3, were defined as the $l^{2}$-norms of the corresponding strain vectors [21-23]. The models for damage propagation are shown in Table 3.

In the above table, $d_{f i b}^{T / C}$ are the damage parameters for fibre-dominated tensile/compressive failure. $d_{\text {mat }}$ and $d_{i}(i=1,2,3)$ are the damage parameters for matrix-dominated failure in a UD ply and the damage parameter for matrix-dominated failure in a woven ply, respectively. $\varepsilon_{f i b}^{T / C}$ represents the current tensile /compressive strain in the fibre-dominated direction. $\varepsilon_{f i b}^{O T / O C}$ and $\varepsilon_{f i b}^{F T / F C}$ refer to the tensile /compressive strains at damage initiation and final failure, in the fibre-dominated direction, respectively. For the UD ply, $\varepsilon_{r}$ is the current combined strain on the fracture surface defined in Puck's criteria. $\varepsilon_{r, i n}^{0}$ refers to the combined inelastic strain at damage initiation on the fracture surface. $\varepsilon_{r}^{0}$ and $\varepsilon_{r}^{f}$ are the combined strain, on the fracture surface, corresponding to damage initiation and final failure, respectively. On the surfaces $\mathrm{W} 1, \mathrm{~W} 2$ and $\mathrm{W} 3$ defined in the woven ply, $\varepsilon_{i}(i=1,2,3)$ and $\varepsilon_{i}^{f}(i=1,2,3)$ are the current combined strain and final failure strain, respectively. $\varepsilon_{i}^{0}(i=1,2,3)$ is the combined strain at damage initiation and $\varepsilon_{i, i n}^{0}(i=1,2,3)$ is the combined inelastic strain at damage initiation.

\subsection{Element deletion}

Generally, if the fibre-dominated damage has been activated, the relevant elements will start to degrade and finally these damaged elements will be deleted. In the presented model, different damage modes were considered, and the stress condition might be very complicated. Consequently, there are often instances when considerable matrix damage has been accumulated but fibre- 
dominated damage has yet to be activated, or is relatively low, which would imply that a largely deformed element may still be able to support subsequent loading. This poses a challenge to the modelling of composites crushing behaviour. Deleting an element based on the accumulated damage in one mode, may lead to premature element deletion and reduce the accuracy of the simulation. Conversely, highly distorted elements may lead to a negative Jacobian of the transformation matrix, which may cause the solution to abort. In order to deliver a robust and accurate solution process, these two considerations need to be balanced.

Since the Jacobian of the transformation matrix is not readily available within a VUMAT subroutine in Abaqus/ Explicit, the element deletion criterion was based on the determinant of the deformation gradient, Det $\boldsymbol{F}$, which is an internal variable transferred to the VUMAT subroutine. Det $\boldsymbol{F}$ yields the ratio of the deformed volume, $V$, and undeformed, $V_{0}$ volume, of an element [26],

$$
\text { Det } \boldsymbol{F}=\frac{V}{V_{0}}
$$

and provides a reasonable indication of element distortion. The overall element distortion criterion

was subsequently based on both the fibre-dominated longitudinal damage parameter, $d_{f i b}^{T(C)}$, and limits on Det $\boldsymbol{F}$ for tracking large element deformation [6],

$$
\text { Delete element if }\left\{\begin{array}{c}
d_{f i b}^{T(C)}>0.99 \\
\text { Det } \boldsymbol{F}<0.6 \text { or Det } \boldsymbol{F}>1.8
\end{array} .\right.
$$

The limits on Det $\boldsymbol{F}$ are user defined and the quoted values were found to yield reliable results. For more details of the present composite damage model, please refer to $[6,17,20,22,24,25,27]$.

\section{Finite element model}

\subsection{Material properties}

Material characterisation tests reported in [28-31] were undertaken to extract the appropriate input parameters for the computational model. $E_{i i}(i=1,2,3)$ are the moduli of the employed composite ply. $G_{i j}(i j=1,2,3)$ and $v_{i j}(i j=1,2,3)$ represent the shear modulus and Poisson's ratio of the composite 
ply, respectively. $X^{T}$ and $X^{C}$ are the longitudinal/warp-direction tensile and compressive strength of the composite ply, respectively. $Y^{T}$ and $Y^{C}$ refer to the transverse/weft-direction tensile and compressive strength of the composite ply, respectively. $S_{12}$ represents the in-plane shear strength of the employed composite ply. The interlaminar fracture toughness, $G_{I C}$ and $G_{I I c}$, and the BenzeggaghKenane (B-K) exponent, $\eta$, for UD-only and woven-only laminates were determined using standard double-cantilever-beam (DCB), four-point end-notched-flexure (4ENF) and mixed-mode-beam (MMB) tests, respectively. Due to the non-symmetrical lay-up, it is not easy to measure the interfacial properties between UD and woven plies. An approximation was adopted where the interfacial properties between UD and woven plies, such as interfacial strength and interlaminar fracture toughness, were taken to be the average values of interfacial properties measured from the UD-only and woven-only laminates. Consequently, the interlaminar mode I and mode II fracture toughness, for the interface between the UD ply and woven ply, were $0.39 \mathrm{~kJ} / \mathrm{m}^{2}$ and $1.76 \mathrm{~kJ} / \mathrm{m}^{2}$, respectively. Likewise, the interfacial tensile and shear strengths $\left(\sigma_{I}\right.$ and $\left.\sigma_{I I}\right)$ for the interface between the UD ply and woven ply were determined to be $18.5 \mathrm{MPa}$ and $32 \mathrm{MPa}$, respectively. The mode I intralaminar fracture toughness, $\left.G_{I c}\right|_{f t}$, associated with fibre-dominated tensile failure was measured using a compact tension test. The mode I intralaminar fracture toughness, $\left.G_{I c}\right|_{f c}$, associated with fibredominated compressive failure was measured using a compact compression test. The intralaminar fracture toughness associated with matrix-dominated tensile, $\left.G_{I c}\right|_{m t}$, failure was assumed to be similar to the interlaminar mode I fracture toughness, $G_{I c}$. the intralaminar matrix-dominated compressive and shear fracture toughness, $\left.G_{I c}\right|_{m c}$ and $\left.G_{I I C}\right|_{m s}$, were deemed to be similar to the interlaminar mode II fracture toughness, $G_{\text {IIC }}[9,32,33]$. The standard V-notched rail shear (VRS) test method [32] was used to obtain the non-linear shear response and determine the nonlinear shear coefficients $\left(c_{1}, c_{2}\right.$ and $\left.c_{3}\right)$. The material properties are shown in Table 4 .

\subsection{Model definition}

The set-up for the virtual crush test is shown in Fig. 6a. The chamfered virtual crush specimens were created in Abaqus/Explicit, as shown in Fig. 6b. The trigger of the specimen was meshed using an approximate element size of $0.25 \mathrm{~mm}$ in the longitudinal directional and $0.5 \mathrm{~mm}$ in the transverse direction. For the main part of the specimen, element size was defined as $0.5 \mathrm{~mm}$ in both longitudinal and transverse directions $[6,34,35]$. The fixed part of the testing specimen was created as a rigid 
body. In order to capture the bending behaviour, three C3D8R elements were used, per ply, in the thorough-thickness direction. The total number of elements in this finite element model was 14230 . The general contact algorithm and surface-based cohesive behaviour were used to govern the global contact and composite interface contact, respectively [36]. An enhanced stiffness-based hourglass and distortion control were employed to suppress spurious energy modes. The compression head and support fixture were set as rigid bodies. The friction coefficients of 0.2 and 0.25 were used for metal/composites and ply/ply interfaces, respectively $[6,32]$. The computational loading speed was fixed at $1 \mathrm{~m} / \mathrm{s}$, to reduce computation time whilst ensuring that the quality of the simulation was not affected by inertial effects. In order to achieve an acceptable simulation time, selective mass scaling was used to scale elements, which had a stable time increment below $1 \mathrm{e}-08 \mathrm{~s}$, during the virtual crushing process. Computations were completed using 16 CPUs on a Windows Cluster with a run time of between 16 and $20 \mathrm{~h}$, depending on the specimen type.

\section{Results and discussions}

\subsection{Overall response of hybrid UD/woven composite specimens}

The load-displacement curves for both types of samples; bevel-trigger samples and steeple-trigger samples, were obtained from the experimental results as shown in Figs. $7 \mathrm{a}$ and $7 \mathrm{~b}$, respectively. For the bevel-trigger samples, prior to the peak load, the composite laminates presented a growing overall loading response, with a number of small load drops caused by the progressive failure of the triggers. Micro-cracks were observed early in the trigger when the load was increasing. After reaching the maximum value, the load stayed around the peak level when the displacement increased from 2.5 $\mathrm{mm}$ to $3.2 \mathrm{~mm}$. At this stage, larger cracks were initiated in the laminates below the trigger, which then caused a large drop in the loading curve. A short increase in the loading response was observed after the large drop, duo to support from the remaining un-damaged parts, which then also fractured with the increasing load. Due to the progressive failure and the loss of the load-bearing capability, the laminates showed consecutively decreasing loading response. For the steeple-trigger samples, similar increasing stage, along with some micro-cracks in the trigger, was observed before the maximum load point. Differently, more rapid decline was delivered by the steeple-trigger sample after the peak point in the loading curve. This may be caused by the higher load, which forced the main crack underneath the trigger to grow quickly. For comparison, the corresponding results obtained 
using the proposed damage model are also presented in these figures. It is shown that the predicted initial stiffness, peak force and damage propagation of both bevel-trigger and steeple-trigger composite laminates were accurately captured by the numerical model. Excellent quantitative correlation was achieved between experimental and numerical results, which prove the capability of the proposed damage model to distinguish the load response of composite components with different trigger geometries.

\subsection{Crashworthiness evaluation of hybrid UD/woven composite specimens}

In this work, the crashworthiness performance, including crush energy, maximum force and SEA of crush samples with different trigger geometries were obtained from the experiment and simulation are shown in Table 5. Steeple-trigger samples presented a larger average maximum force than the beveltrigger samples. Steeple-trigger samples also have a higher average SEA than the bevel-trigger samples. For the bevel-trigger specimens, the simulated SEA and maximum stress are only $7.3 \%$ and 3.8\% lower than the corresponding experimental average values, respectively. For the steeple-trigger specimens, the simulated SEA and peak-load are $6.1 \%$ and $3.7 \%$ lower than the corresponding experimental average values, respectively.

As in Figs. 8a and 8b, intralaminar failure, e.g. fibre breakage and matrix cracking, dissipated most of the absorbed energy in the crush event; around $40 \%$ for bevel-trigger samples and $53 \%$ for steepletrigger samples. Frictional energy, which consumed $32 \%$ and $19 \%$ of the total energy for bevel-trigger samples and steeple-trigger samples, respectively, also played an important role in the energy dissipation of the crush events. Good agreement was obtained between experimental and computational total energy absorption.

\subsection{Damage morphology of crushed hybrid UD/woven composite laminates}

Figs. 9a and 9b present typical photographic and microscopic images of the morphology obtained from damaged bevel-trigger crush samples. Correspondingly, the photograph and micrograph obtained for crushed steeple-trigger samples are shown in Figs. 10a and 10b respectively, where details of the crush features such as fibre breakage/splitting, matrix cracking and delamination are indicated. In the photographs taken from the crushed bevel-trigger samples and steeple-trigger 
samples, composite plies were observed to splay and spread outward. Due to the different trigger geometries, asymmetrical damage morphology was exhibited by the bevel-trigger samples, in contrast to the symmetrical damage morphology of steeple-trigger samples. Fragmentation and buckling of the plies at the crush front, observed from the micrographs, were evident, due to the combined action of compression and friction. This phenomenon indicates that friction has considerable influence on the crush response and damage morphology of composite laminates.

Images of the damage evolution for bevel-trigger crush samples are presented in Fig. 11. Delamination initiated from the contact region, as expected (stage 1), and followed by the formation of micro-cracks around the trigger tip which propagated longitudinally (stage 2). With the consumption of the trigger, the dominant delamination kept propagating and forced the outer ply to split from the sample, as the new delamination were created in the centre of the specimen, forcing the sublaminates to bend away from each other (stage 3 to stage 4). Afterwards, the main fracture planes, which had an angle with the crushing direction, were formed in the laminates, forcing chunks of the material to break off from the laminates and form the fragmentations. The increase in delamination, bending of plies and fracture resulted in a significant dip in loading and catastrophic failure in the laminates. With the growth of failure, the laminates finally lost the load-bearing capability. As shown in the figure, the simulation results presented very similar failure process as the experimental results for the bevel-trigger crush samples.

Images of the damage evolution for the steeple-trigger samples are shown in Fig. 12. The initial delamination, appeared in the central part of the specimen, caused the sub-laminates to separate from each other (stage 1 to stage 2). The delaminated specimen was forced to splay, and the separated two parts were compelled to move to the periphery area. During this process, the separated two parts would carry the load together and presented an elastic bending behaviour. Owing to the relatively high bending stiffness of these sub-laminates, load would keep increasing during this process (stage 2 to stage 3 ), whilst more cracks were initiated with the increased (stage 3 to stage 4 ). The bended sub-laminates would eventually fractured with the increasing deformation and further delamination, which was observed as the catastrophic failure. For comparison, the corresponding simulation was conducted, and the results were shown in the figure. It can be found that the failure 
mechanisms including ply splitting, fragmentation and matrix cracking were captured with good accuracy by the computational model.

\subsection{Comparison between hybrid UD/woven composites and UD-only composites}

To investigate the difference between the crush responses of the hybrid UD/woven composites and the UD-only composites, the validated predictive model was used to simulate the crush events of these two types of composite specimens with bevel-triggers. Fig. 13a shows the load versus displacement trace obtained from the virtual hybrid UD/woven bevel-trigger composite specimen and the UD-only bevel-trigger composite specimen. It shows that the hybrid UD/woven composite specimen delivered a lower maximum load but a higher stead-state load than the UD-only composite specimen. The maximum load and SEA of the virtual hybrid UD/woven composite specimen and the UD-only composite specimen are normalised, with respect to the results of the hybrid UD/woven specimen, and compared in Fig. 13b. The hybrid UD/woven composite specimen presented a maximum load of $4.59 \mathrm{kN}$ and a SEA of $60.5 \mathrm{~kJ} / \mathrm{kg}$, which are $10 \%$ lower and $2 \%$ higher than those shown by the UD-only composite specimen, respectively. This indicates that the UD/woven composite has a slightly better crashworthy performance than the UD-only composite.

\subsection{Effects of friction on the crush response of hybrid UD/woven composites}

As reported in other studies (e.g. [34,37]), the energy consumed by external friction can be substantial, and this was also confirmed by the modelling of energy dissipation presented in this work (Table 7). The following brief study further explores the effects of friction on the crush response of composite laminates. The fully validated predictive model was used to perform the virtual crush tests on the bevel-trigger specimens, where two different friction coefficients, the previously measured standard friction coefficient (SFC, 0.2) and a doubling of this friction coefficient (DFC, 0.4) were defined for the global contact, on the bevel-trigger samples. The crush response and damage morphology obtained from these virtual crush tests were compared to show the effect of friction in the crush event.

The load vs displacement curves obtained from SFC and DFC models are compared in Fig. 14a, where the experimental results (black solid curves) are also presented for comparison. As expected, 
the virtual crush tests with a higher friction coefficient, DFC, presented a higher peak load (5.3 kN) than the virtual SFC tests. The total energy dissipation in the DFC simulation was $19.1 \mathrm{~J}$, which was $16.5 \%$ higher than the $16.4 \mathrm{~J}$ delivered by SFC simulation. The increased energy dissipation was due to higher frictional energy, from $5.3 \mathrm{~J}$ in the SFC simulation to $6.8 \mathrm{~J}$ in the DFC simulation, which, in turn, also facilitated an increase in intralaminar energy dissipation, from $6.5 \mathrm{~J}$ in the SFC simulation to 7.6 $\mathrm{J}$ in DFC simulation, as shown in Fig. 14b.

\section{Conclusions}

This work presented a detailed methodology, which combined experimental and numerical work for the development of a predictive computational model, which was used to evaluate the crush behaviour of hybrid carbon-fibre reinforced composites. The influence of the trigger geometries on the crush behaviour of the specimens was explored by performing crush experiments on simplified crushing specimens with two different trigger geometries. A physically based damage model was developed to undertake a numerical investigation of the crush behaviour of hybrid composite laminates. Excellent qualitative and quantitative correlation was achieved between experiment and simulation.

Both experimental and numerical results showed that steeple-trigger samples presented higher specific energy absorption and peak load than bevel-trigger samples. A comparative study on the crushing responses of the hybrid unidirectional/woven and unidirectional-only (UD-only) specimens showed that the hybrid unidirectional/woven specimen presented slightly better crashworthy performance than the unidirectional-only specimen did, by delivering higher steady-state load and specific energy absorption. The numerical investigation on the effects of friction during a crush event showed that the increased friction reduced ply splaying, which facilitated a larger extent of energy dissipation by generating more intralaminar damage in the composite laminates. The developed model can provide a useful design tool for enhancing the crashworthiness of composite structures, which should be of particular relevance to the transport sector.

\section{Acknowledgements}


The authors are indebted to Dr Wei Tan from University of Cambridge for his suggestions and discussions. Supports from the Research Computing Team at QUB in accessing the HPC facilities are also gratefully acknowledged.

\section{References}

[1] Patel S, Vusa VR, Guedes Soares C. Crashworthiness analysis of polymer composites under axial and oblique impact loading. Int J Mech Sci, 2019;156:221-34.

[2] Luo H, Yan Y, Meng X, Jin C. Progressive failure analysis and energy-absorbing experiment of composite tubes under axial dynamic impact. Compos Part B Eng, 2016;87:1-11.

[3] Xiao X. Modeling Energy Absorption with a Damage Mechanics Based Composite Material Model. $J$ Compos Mater, 2009;43:427-44.

[4] Hallquist J. LS-DYNA theory manual. Livermore Livermore Softw Technol Corp, 2006.

[5] Joosten MW, Dutton S, Kelly D, Thomson R. Experimental and numerical investigation of the crushing response of an open section composite energy absorbing element. Compos Struct, 2011;93:682-9.

[6] Tan W, Falzon BG. Modelling the crush behaviour of thermoplastic composites. Compos Sci Technol, 2016;134:57-71.

[7] Zhou H, Pan Z, Gideon RK, Gu B, Sun B. Experimental and numerical investigation of the transverse impact damage and deformation of 3-D circular braided composite tubes from meso-structure approach. Compos Part B Eng, 2016;86:243-53.

[8] Jiang H, Ren Y, Gao B, Xiang J, Yuan FG. Design of novel plug-type triggers for composite square tubes: enhancement of energy-absorption capacity and inducing failure mechanisms. Int J Mech Sci, 2017; 131-132:113-36.

[9] Rolfe E, Quinn R, Sancho A, Kaboglu C, Johnson A, Liu H, et al. Blast resilience of composite sandwich panels with hybrid glass-fibre and carbon-fibre skins. Multiscale Multidiscip Model Exp Des, 2018;1:197210.

[10] ASTM. Standard Test Method for Tensile Properties of Fiber Reinforced Metal Matrix Composites, D3552-12, West Conshohocken, PA. 2012.

[11] ASTM. Standard Test Method for Compressive Properties of Polymer Matrix Composite Materials Using a Combined Loading Compression (CLC) Test Fixture, D6641 / D6641M, West Conshohocken, PA. 2009.

[12] ASTM. Standard Test Method for Short-Beam Strength of Polymer Matrix Composite Materials and Their Laminates, D2344/D2344M-16, West Conshohocken, PA. 2016.

[13] ASTM. Standard Test Method for In-Plane Shear Properties of Polymer Matrix Composite Materials by the Rail Shear Method, D4255 / D4255M-14, West Conshohocken, PA. 2014.

[14] Bru T, Waldenström P, Gutkin R, Olsson R, Vyas GM. Development of a test method for evaluating the crushing behaviour of unidirectional laminates. J Compos Mater, 2017;3:1-11.

[15] Wang C, Zhong Y, Bernad Adaikalaraj PF, Ji X, Roy A, Silberschmidt V V., et al. Strength prediction for bi-axial braided composites by a multi-scale modelling approach. J Mater Sci, 2016;51:6002-18.

[16] Hashin Z, Rotem A. Failure Criterion for Fiber Reinforced Materials. J Compos Mater, 1973;7:448-64

[17] Falzon BG, Apruzzese P. Numerical analysis of intralaminar failure mechanisms in composite structures. Part I FE implementation. Compos Struct, 2011;93:1039-46.

[18] Catalanotti G, Camanho PP, Marques AT. Three-dimensional failure criteria for fiber-reinforced laminates. Compos Struct, 2013;95:63-79.

[19] Puck A, Schürmann H. Failure analysis of FRP laminates by means of physically based phenomenological models. Compos Sci Technol, 1998;58:1045-67.

[20] Falzon BG, Liu H, Tan W. Comment on A tensorial based progressive damage model for fiber reinforced polymers. Compos Struct, 2017;176:877-82.

[21] Liu H, Falzon BG, Tan W. Predicting the Compression-After-Impact (CAI) strength of damage-tolerant hybrid unidirectional/woven carbon-fibre reinforced composite laminates. Compos Part A Appl Sci Manuf, 2017; 105:189-202.

[22] Liu H, Falzon BG, Tan W. Experimental and numerical studies on the impact response of damagetolerant hybrid unidirectional/woven carbon-fibre reinforced composite laminates. vol. 136. Elsevier; 2018.

[23] Tan W, Falzon BG, Chiu LNS, Price M. Predicting low velocity impact damage and Compression-AfterImpact (CAI) behaviour of composite laminates. Compos Part A Appl Sci Manuf, 2015;71:212-26.

[24] Falzon BG, Apruzzese P. Numerical analysis of intralaminar failure mechanisms in composite structures. Part II: Applications. Compos Struct, 2011;93:1047-53.

[25] Liu H, Falzon BG, Li S, Tan W, Liu J, Chai H, et al. Compressive failure of woven fabric reinforced thermoplastic composites with an open-hole: an experimental and numerical study. Compos Struct, 2019;213:108-17.

[26] Donadon MV, lannucci L, Falzon BG, Hodgkinson JM, de Almeida SFM. A progressive failure model for 
composite laminates subjected to low velocity impact damage. Comput Struct, 2008;86:1232-52.

[27] Faggiani A, Falzon BG. Predicting low-velocity impact damage on a stiffened composite panel. Compos Part A Appl Sci Manuf, 2010;41:737-49.

[28] ASTM. Standard Test Method for Mixed Mode I-Mode II Interlaminar Fracture Toughness of Unidirectional Fiber Reinforced Polymer Matrix Composites, D6671/D 6671M-14, West Conshohocken, PA. 2014.

[29] ASTM. Standard Test Method for Determination of the Mode II Interlaminar Fracture Toughness of Unidirectional Fiber-Reinforced Polymer Matrix Composites, D7905/D7905M-14, West Conshohocken, PA. 2014

[30] ASTM. Standard Test Method for Mode I Interlaminar Fracture Toughness of Unidirectional FiberReinforced Polymer Matrix Composites, D5528-14, West Conshohocken, PA. 2014.

[31] ASTM. Standard Test Method for Shear Properties of Composite Materials by V-Notched Rail Shear Method, D7078/D7078M-14, West Conshohocken, PA. 2014.

[32] Tan W, Falzon BG, Price M, Liu H. The role of material characterisation in the crush modelling of thermoplastic composite structures. Compos Struct, 2016;153:914-27.

[33] Haibao Liu, Brian Falzon, Wei Tan. An Experimental Method to Determine the Intralaminar Fracture Toughness of High Strength Carbon-Fibre Reinforced Composite Laminates. 17th Eur. Conf. Compos. Mater., Munich, Germany: 2016.

[34] Tan W, Falzon BG, Price M. Predicting the crushing behaviour of composite material using high-fidelity finite element modelling. Int J Crashworthiness, 2015;20:60-77.

[35] Chiu LNS, Falzon BG, Boman R, Chen B, Yan W. Finite element modelling of composite structures under crushing load. Compos Struct, 2015;131:215-28.

[36] Riccio A, Luca A De, Felice G Di, Caputo F. Modelling the simulation of impact induced damage onset and evolution in composites. Compos Part B Eng, 2014;66:340-7.

[37] Israr HA, Rivallant S, Bouvet C, Barrau JJ. Finite element simulation of 0/90 CFRP laminated plates subjected to crushing using a free-face-crushing concept. Compos Part A Appl Sci Manuf, 2014;62:1625. 


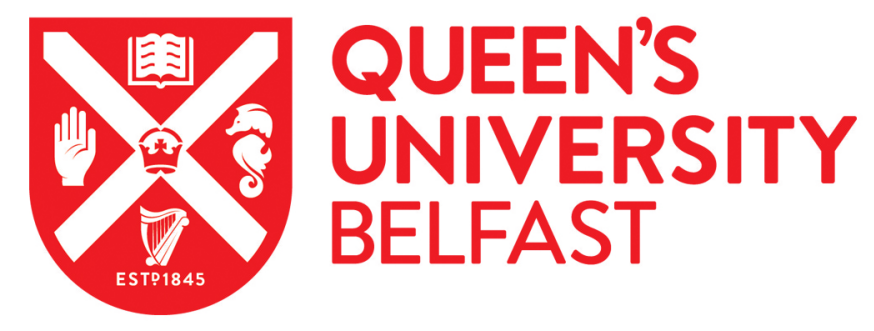

\section{An experimental and numerical study on the crush behaviour of hybrid unidirectional/woven carbon-fibre reinforced composite laminates}

Falzon, B., Liu, H., \& Dear, J. (2019). An experimental and numerical study on the crush behaviour of hybrid unidirectional/woven carbon-fibre reinforced composite laminates. International Journal of Mechanical Sciences.

Published in:

International Journal of Mechanical Sciences

Document Version:

Peer reviewed version

Queen's University Belfast - Research Portal:

Link to publication record in Queen's University Belfast Research Portal

\section{General rights}

Copyright for the publications made accessible via the Queen's University Belfast Research Portal is retained by the author(s) and / or other copyright owners and it is a condition of accessing these publications that users recognise and abide by the legal requirements associated with these rights.

Take down policy

The Research Portal is Queen's institutional repository that provides access to Queen's research output. Every effort has been made to ensure that content in the Research Portal does not infringe any person's rights, or applicable UK laws. If you discover content in the Research Portal that you believe breaches copyright or violates any law, please contact openaccess@qub.ac.uk. 


\section{Figure list}

Fig. 1. (a) Ply stacking for the hybrid laminate incorporating woven plies on the outer surfaces over unidirectional (UD) plies; (b) schematic showing the curing and consolidation of the laminate using a heated press.

Fig. 2. Schematic of the RIFT (Resin Infusion under Flexible Tooling) manufacturing process.

Fig. 3. Geometries of the crush specimens: (a) bevel-trigger specimen; (b) steeple-trigger specimen.

Fig. 4. (a) Schematic showing a specimen mounted in the test fixture; (b) photograph of the experimental set-up.

Fig. 5. The evolution of different fracture planes for the two ply types considered in this work; (a) fracture planes in the UD composite ply; (b) fracture planes in the woven composite ply.

Fig. 6. (a) CAD model of the fixture used to support the sample; (b) a FE model of the bevel-trigger specimen created in Abaqus for the crush simulation.

Fig. 7. (a) Experimental and numerical load-displacement curves for the bevel-trigger samples; (b) experimental and numerical load-displacement curves for the steeple-trigger samples.

Fig.8. Curves of different energy dissipation mechanisms for the two types of samples tested: (a) experimental and simulation energy dissipation results for (a) the bevel-trigger samples; (b) the steeple-trigger samples.

Fig. 9. (a) Photographs of a crushed bevel-trigger sample; (b) detailed microscopic image of a crushed bevel-trigger sample showing the different failure mechanisms.

Fig. 10. (a) Photographs of a crushed steeple-trigger sample; (b) detailed microscopic image of a crushed steeple-trigger sample showing the different failure mechanisms.

Fig. 11. Comparison between experimental and computational damage morphology obtained from the bevel-trigger samples.

Fig. 12. Comparison between experimental and computational damage morphology obtained from the steeple-trigger samples.

Fig. 13. (a) Load-displacement curves obtained from experiment and simulation of the hybrid composite specimen and simulation of the UD-only composite specimen; (b) comparison of the normalised maximum load and SEA obtained from simulations for the hybrid composite specimen and the UD-only composite specimen.

Fig. 14. (a) Load-displacement curves obtained from the simulation with measured friction coefficient (SFC) and one where the friction coefficient was doubled (DFC); (b) comparison of energy dissipation obtained from simulations with SFC and DFC.

\begin{tabular}{|l|l|}
\hline 1 column & $\begin{array}{l}\text { Fig. 1a, Fig. 1b, Fig. 3a, Fig. 3b, Fig. 4a, Fig. 4b, Fig. 5a, Fig. 5b, } \\
\text { Fig. 6a, Fig. 6b, Fig. 7a, Fig. 7b, Fig. 8a, Fig. 8b, Fig. 9a, Fig. 9b, } \\
\text { Fig. 10a, Fig. 10b, Fig. 13a, Fig. 13b, Fig. 14a, Fig. 14b, }\end{array}$ \\
\hline $\mathbf{1 . 5}$ columns & Fig. 2 \\
\hline
\end{tabular}




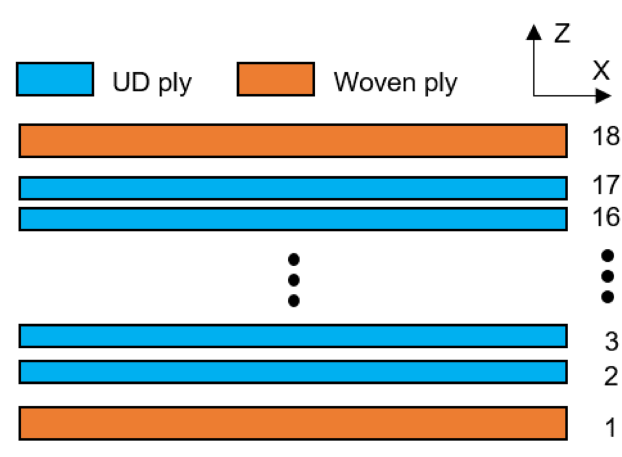

(a)

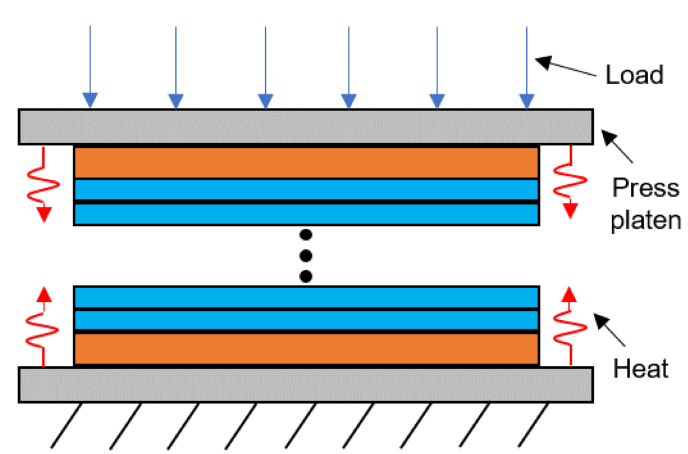

(b)

Fig. 1. (a) Ply stacking for the hybrid laminate incorporating woven plies on the outer surfaces over unidirectional (UD) plies; (b) schematic showing the curing and consolidation of the laminate using a heated press.

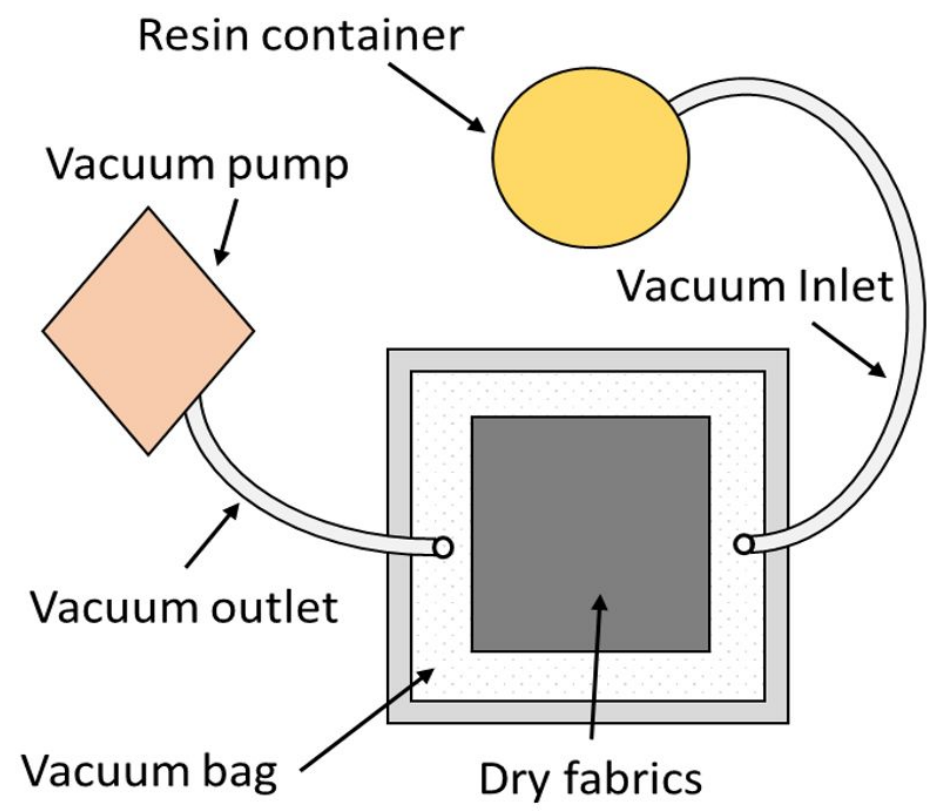

Fig. 2. Schematic of the RIFT (Resin Infusion under Flexible Tooling) manufacturing process. 


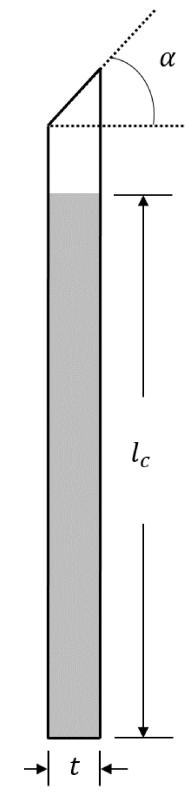

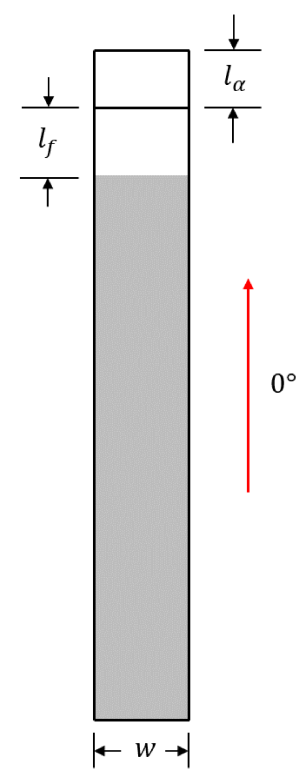

(a)

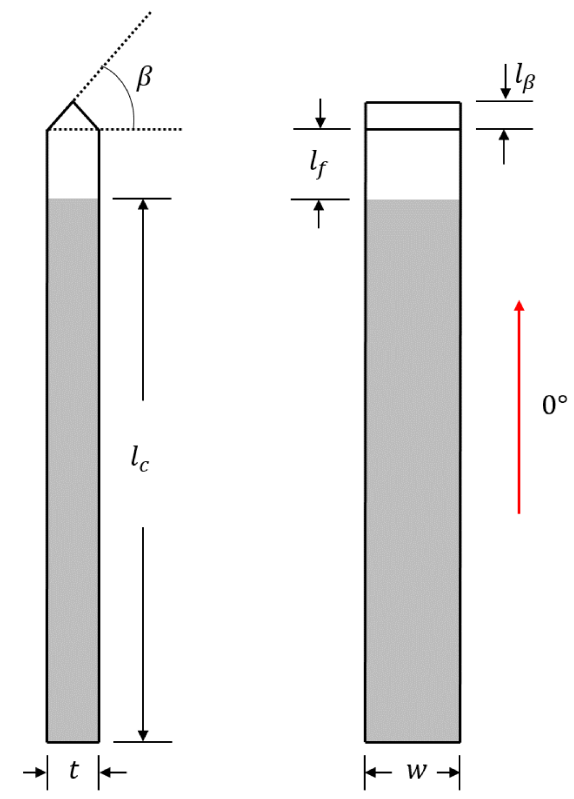

(b)

Fig. 3. Geometries of the crush specimens: (a) bevel-trigger specimen; (b) steeple-trigger specimen.

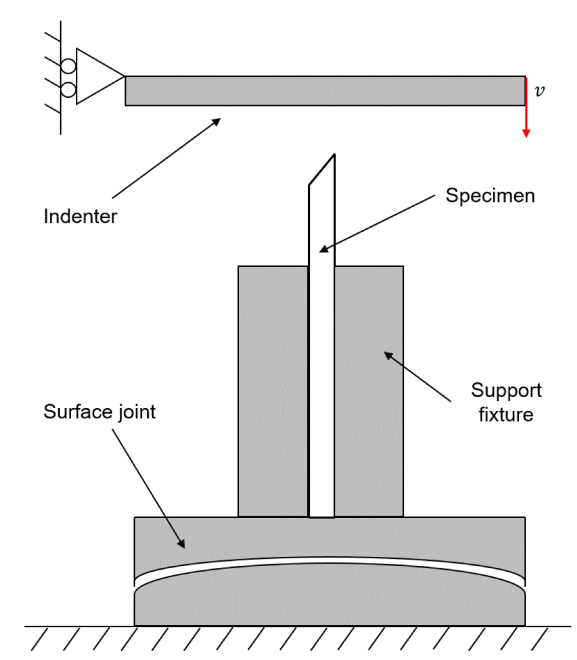

(a)

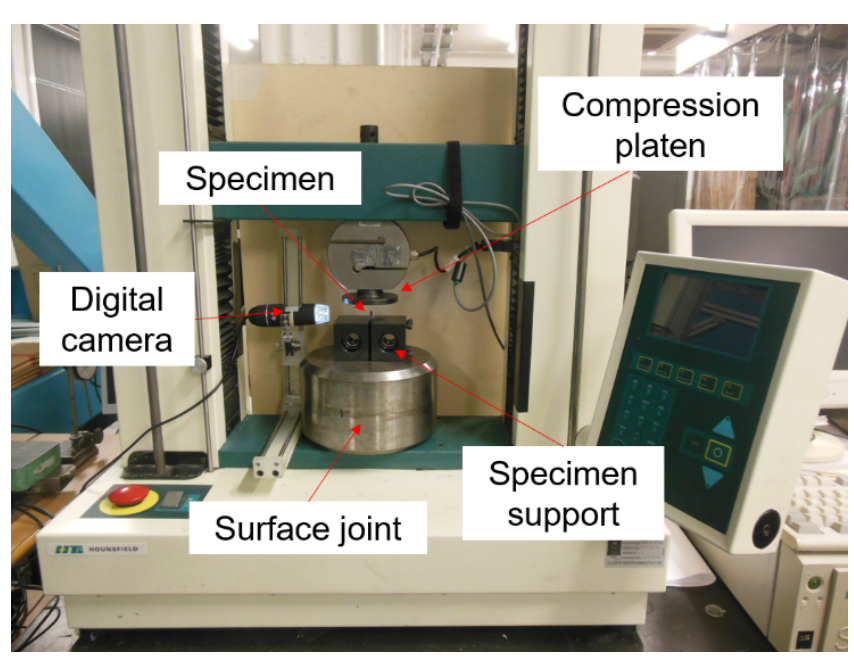

(b)

Fig. 4. (a) Schematic showing a specimen mounted in the test fixture; (b) photograph of the experimental set-up. 


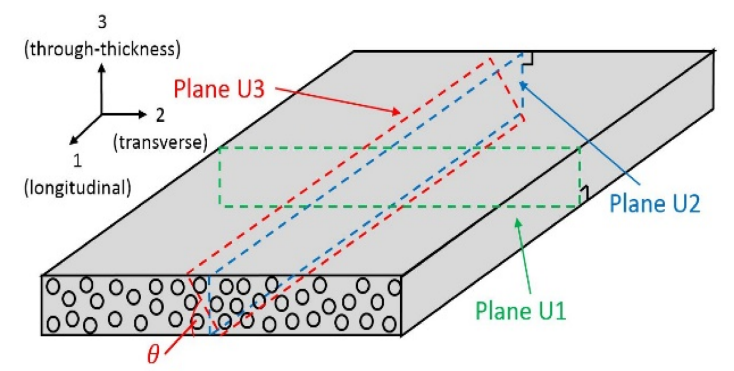

(a)

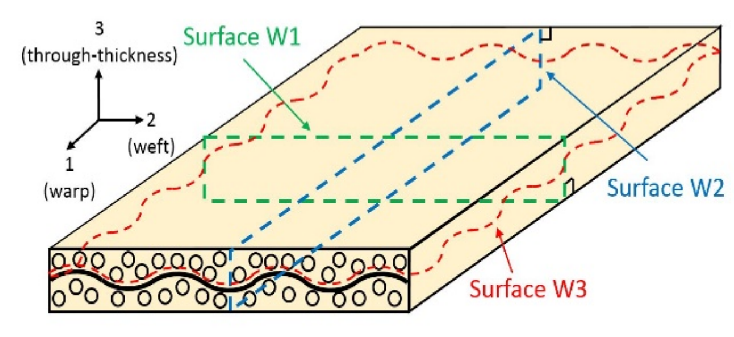

(b)

Fig. 5. The evolution of different fracture planes for the two ply types considered in this work; (a) fracture planes in the UD composite ply; (b) fracture planes in the woven composite ply.

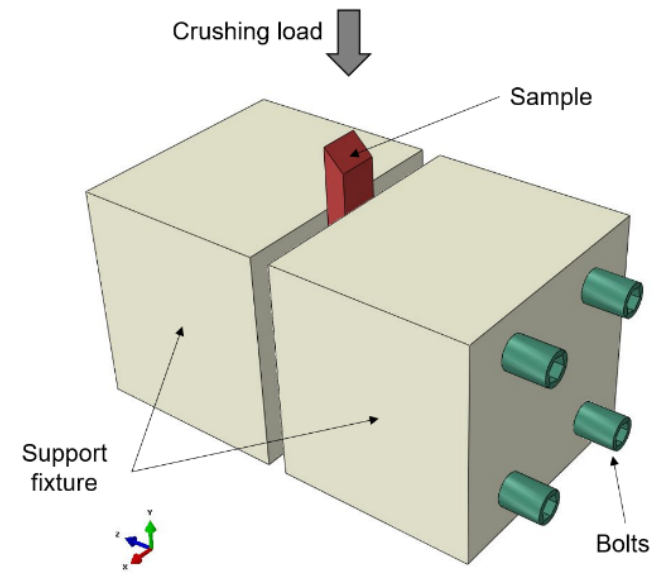

(a)

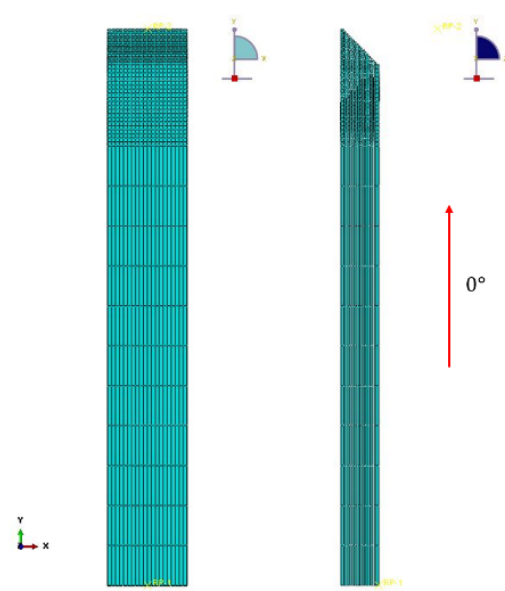

(b)

Fig. 6. (a) CAD model of the fixture used to support the sample; (b) a FE model of the bevel-trigger specimen created in Abaqus for the crush simulation. 


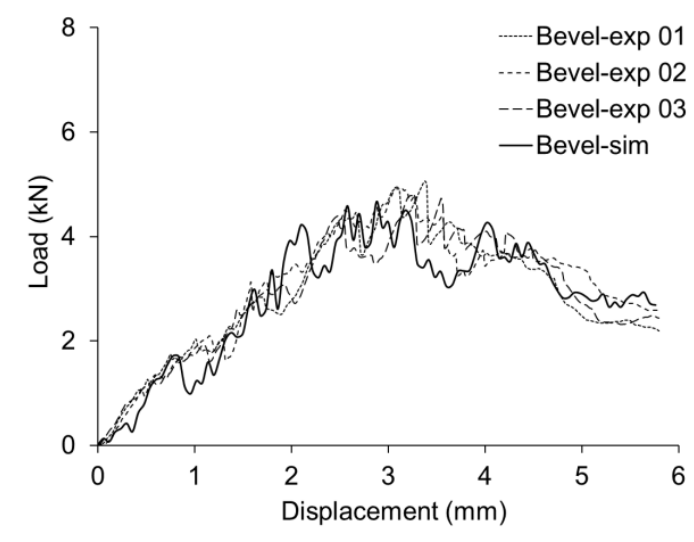

(a)

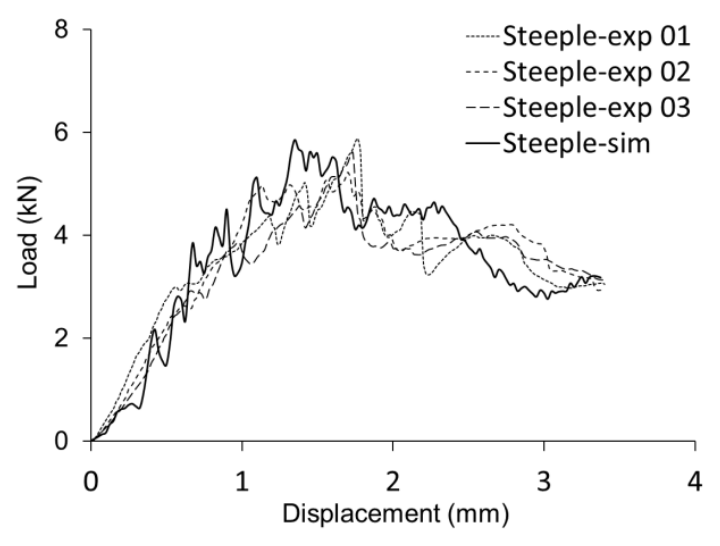

(b)

Fig. 7. (a) Experimental and numerical load-displacement curves for the bevel-trigger samples; (b) experimental and numerical load-displacement curves for the steeple-trigger samples.

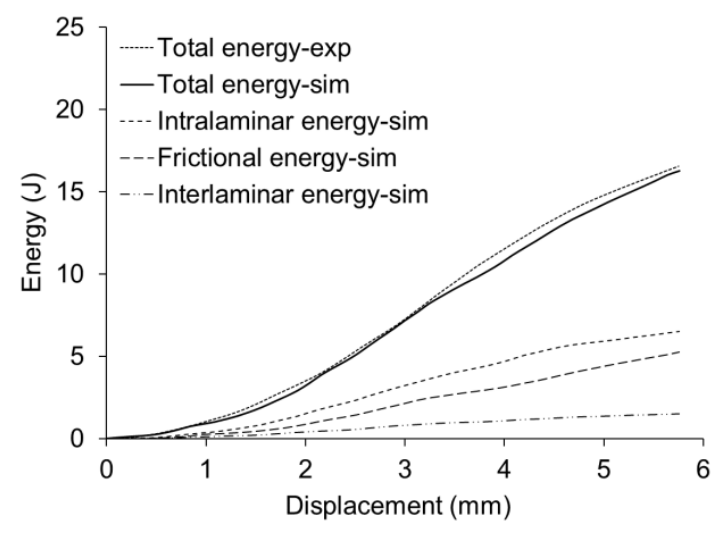

(a)

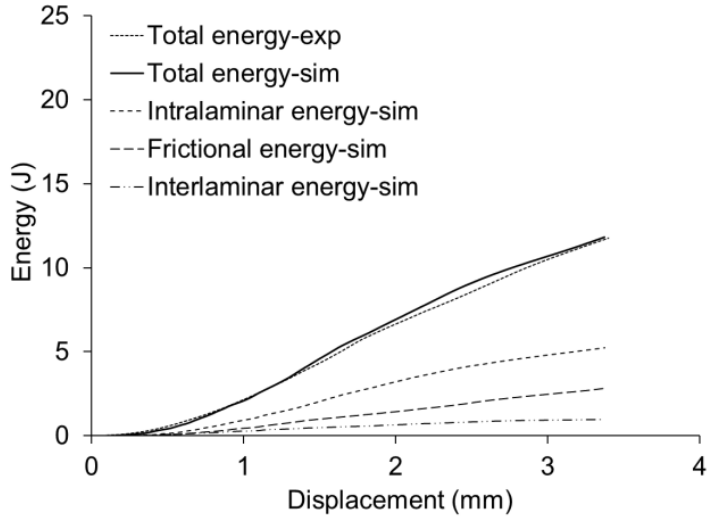

(b)

Fig. 8. Curves of different energy dissipation mechanisms for the two types of samples tested: (a) experimental and simulation energy dissipation results for (a) the bevel-trigger samples; (b) the steeple-trigger samples. 


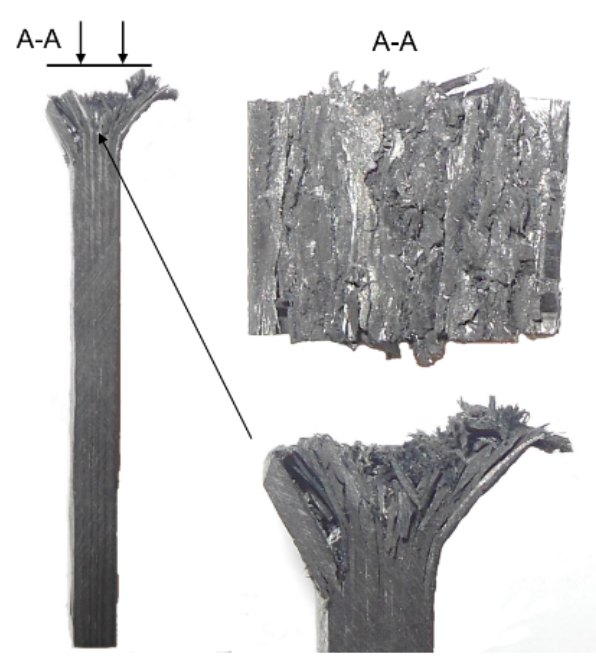

(a)

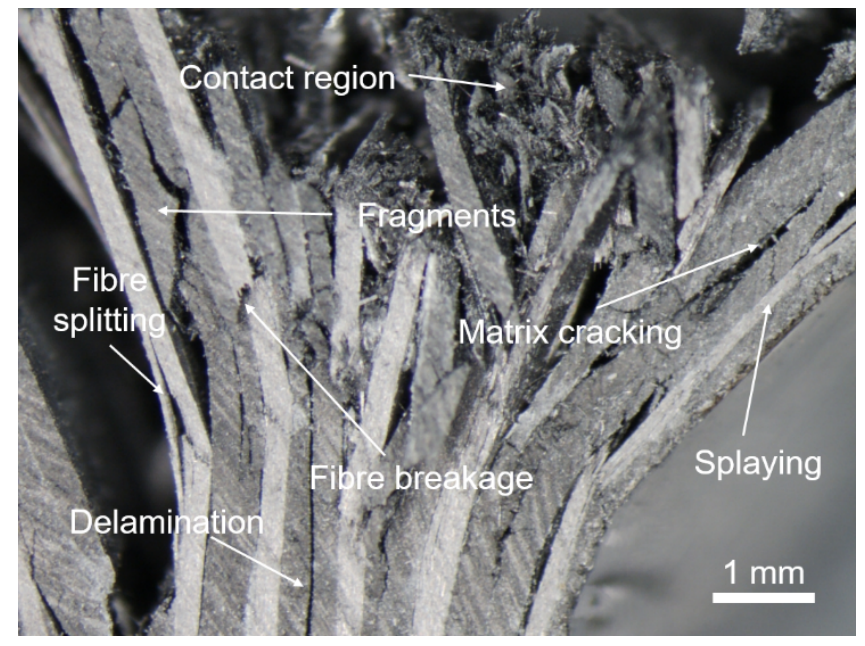

(b)

Fig. 9. (a) Photographs of a crushed bevel-trigger sample; (b) detailed microscopic image of a crushed bevel-trigger sample showing the different failure mechanisms.

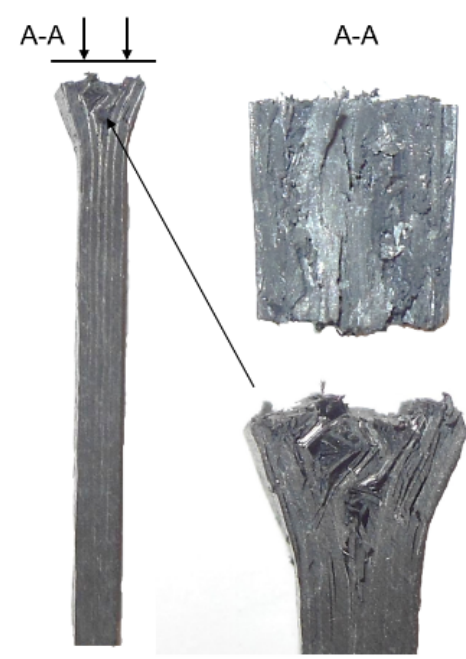

(a)

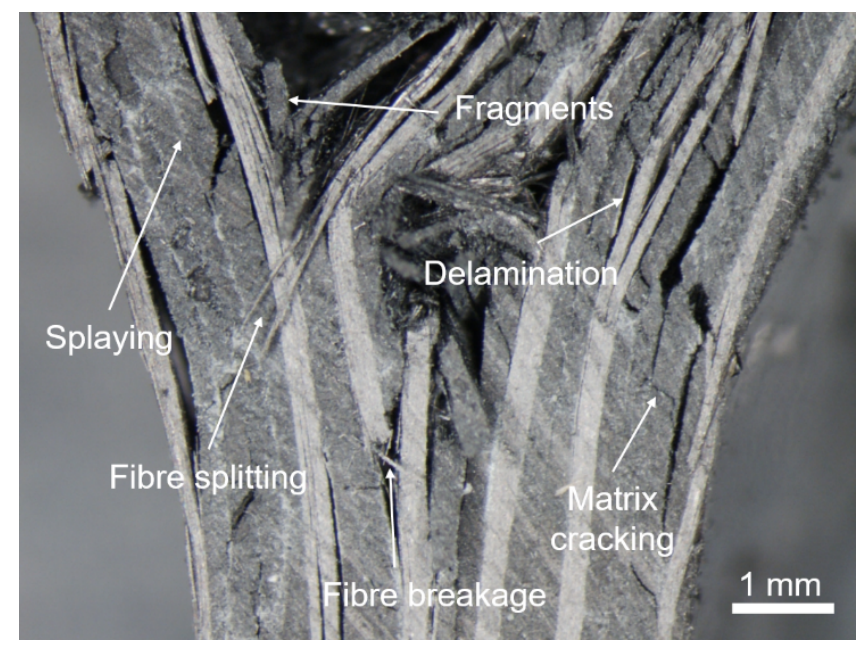

(b)

Fig. 10. (a) Photographs of a crushed steeple-trigger sample; (b) detailed microscopic image of a crushed steeple-trigger sample showing the different failure mechanisms. 

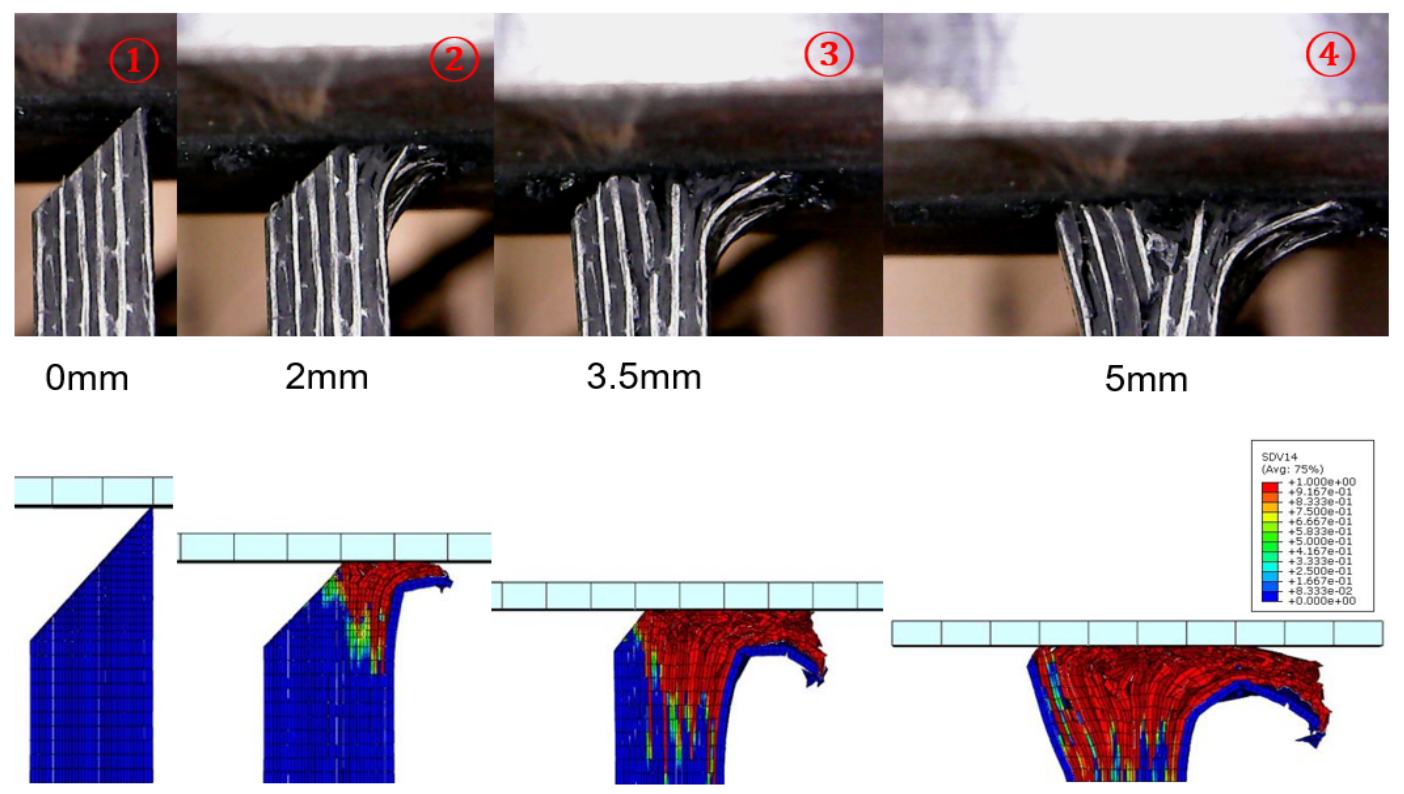

Fig. 11. Comparison between experimental and computational damage morphology obtained from the bevel-trigger samples.

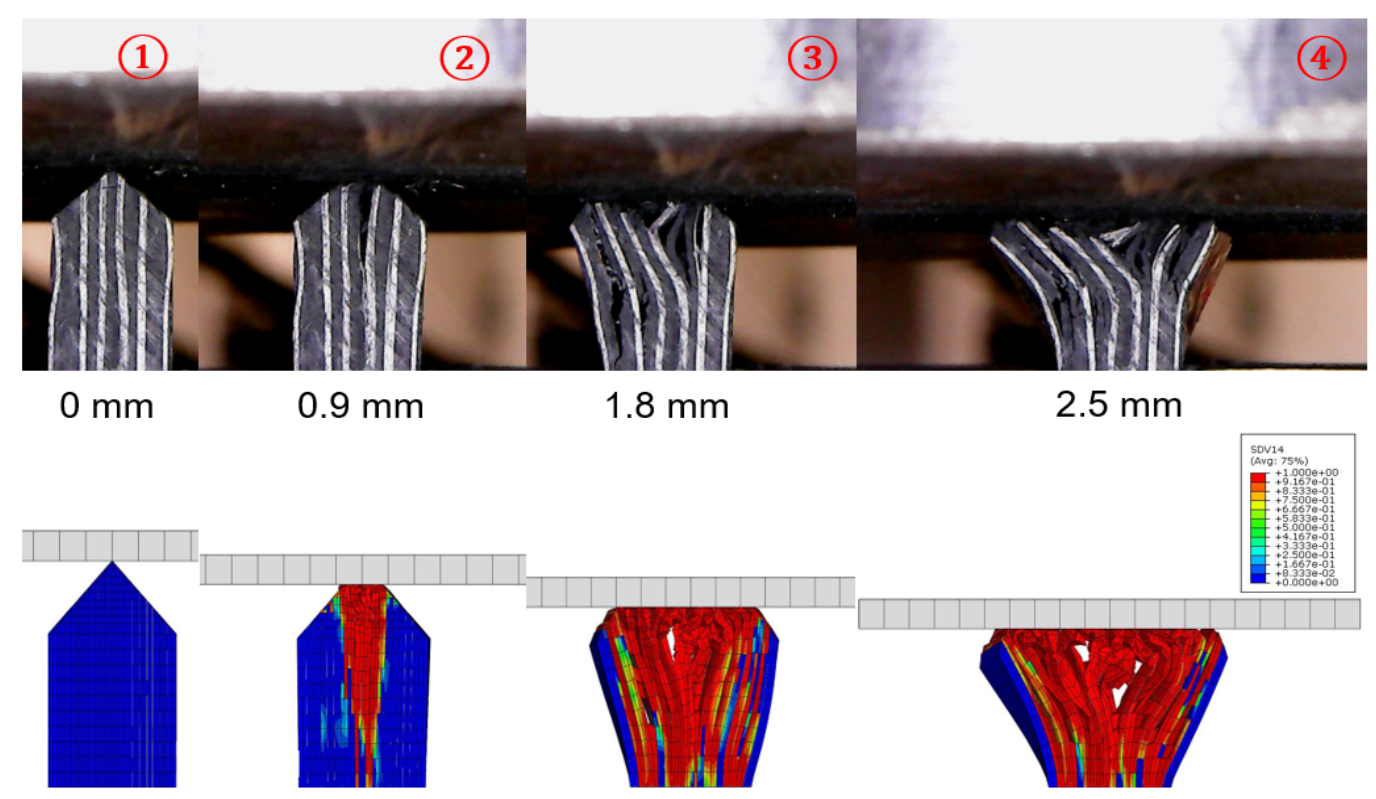

Fig. 12. Comparison between experimental and computational damage morphology obtained from the steeple-trigger samples. 


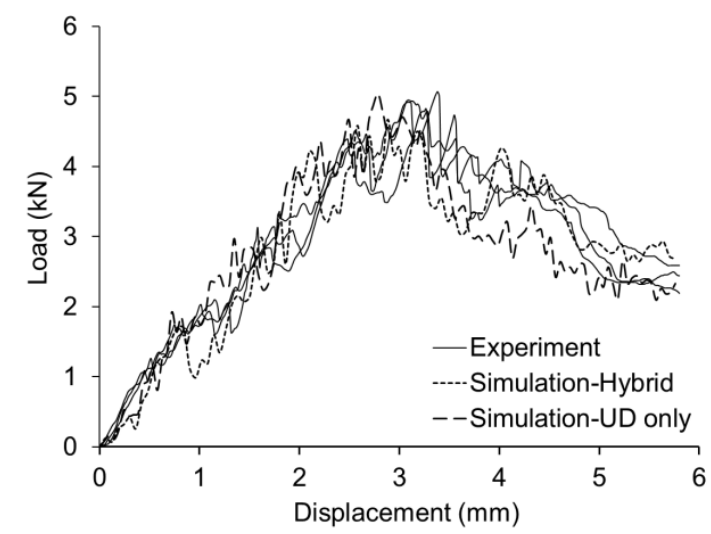

(a)

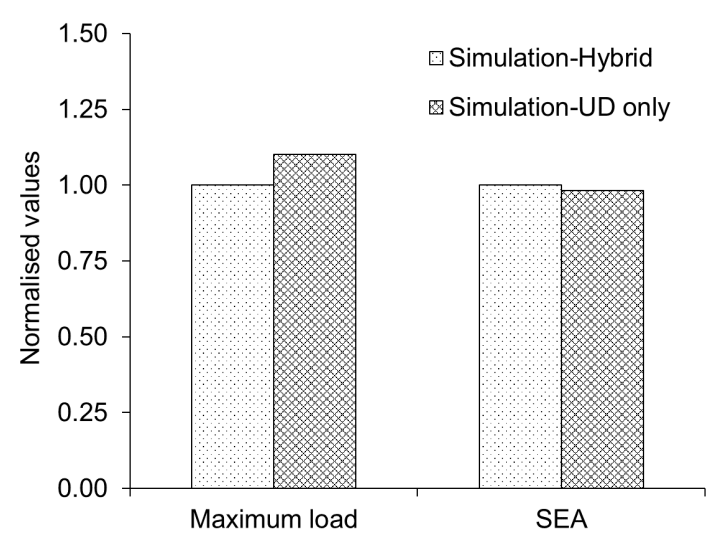

(b)

Fig. 13. (a) Load-displacement curves obtained from experiment and simulation of the hybrid composite specimen and simulation of the UD-only composite specimen; (b) comparison of the normalised maximum load and SEA obtained from simulations for the hybrid composite specimen and

the UD-only composite specimen.

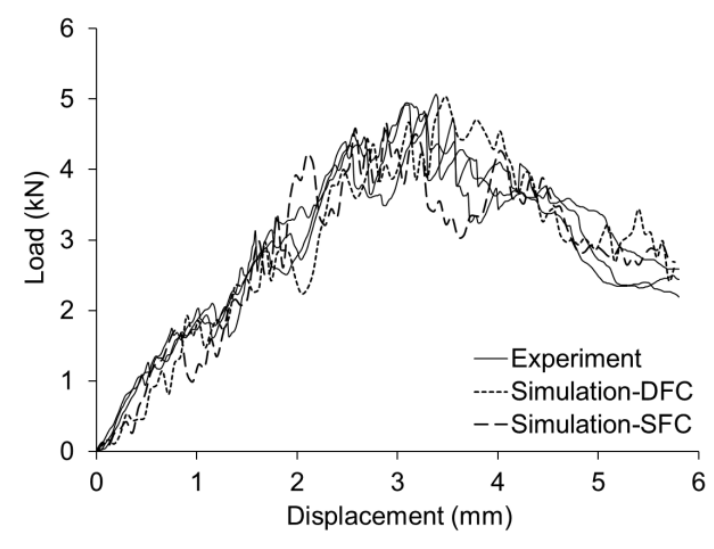

(a)

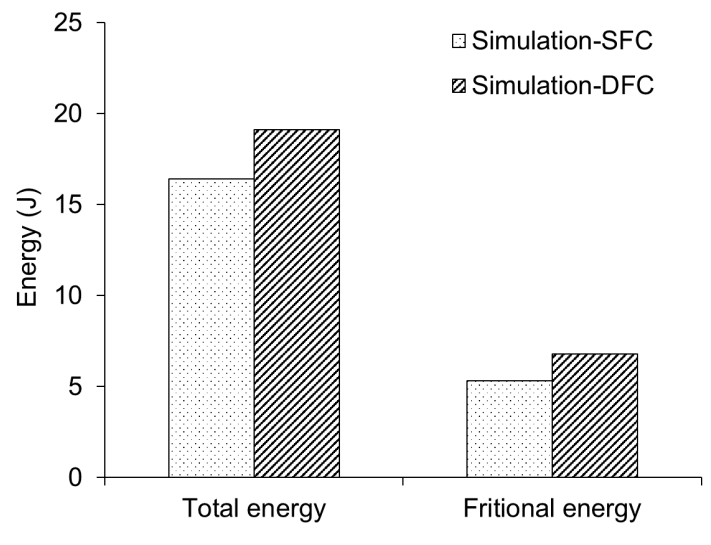

(b)

Fig. 14. (a) Load-displacement curves obtained from the simulation with measured friction coefficient (SFC) and one where the friction coefficient was doubled (DFC); (b) comparison of energy dissipation obtained from simulations with SFC and DFC. 


\section{Table list}

Table 1 Dimensions of the specimens for quasi-static crushing tests.

Table 2 Damage initiation criteria for the computational model.

Table 3 Damage propagation criteria for the computational model.

Table 4 Material properties for IMS60 UD carbon-fibre/epoxy and AS4 woven carbon-fibre/epoxy.

Table 5 Experimental and simulation results of crashworthiness performance.

\section{Table 1}

Dimensions of the specimens for quasi-static crushing tests.

\begin{tabular}{lllllllll}
\hline Dimensions & $l_{f}(\mathrm{~mm})$ & $l_{c}(\mathrm{~mm})$ & $l_{\alpha}(\mathrm{mm})$ & $l_{\beta}(\mathrm{mm})$ & $w(\mathrm{~mm})$ & $t(\mathrm{~mm})$ & $\alpha$ & $\beta$ \\
\hline Values & 6 & 54 & 4.78 & 2.39 & 10 & 4.78 & $45^{\circ}$ & $45^{\circ}$
\end{tabular}

\section{Table 2}

Damage initiation criteria for the computational model.

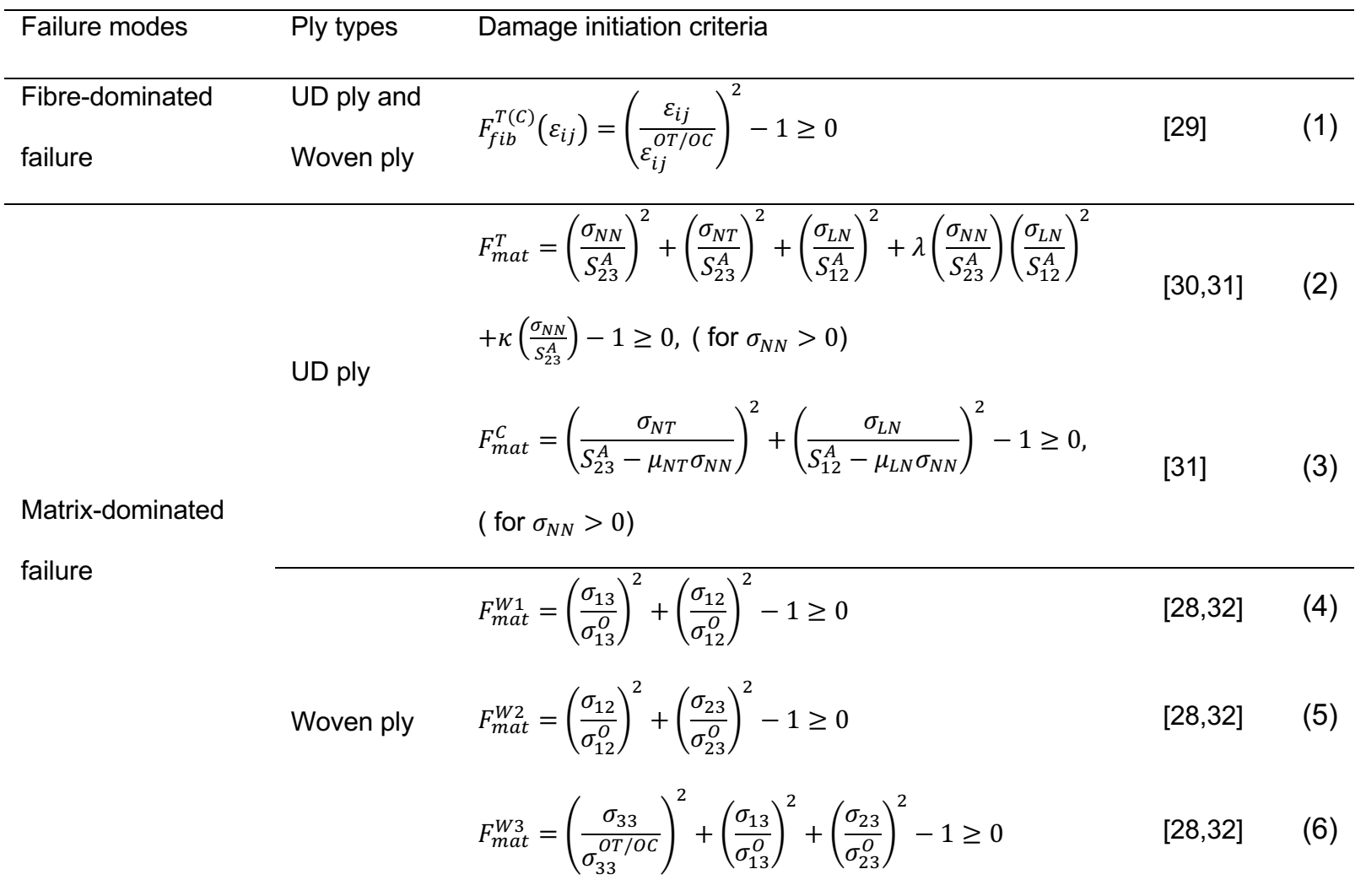




\section{Table 3}

Damage propagation criteria for the computational model.

\begin{tabular}{llll}
\hline Failure models & Composite ply types & Damage propagation criteria \\
\hline Fibre-dominated failure & UD \& Woven plies & $d_{f i b}^{T / C}=\frac{\varepsilon_{f i b}^{F T / F C}}{\varepsilon_{f i b}^{F T / F C}-\varepsilon_{f i b}^{O T / O C}}\left(1-\frac{\varepsilon_{f i b}^{O T / 0 C}}{\varepsilon_{f i b}^{T / C}}\right)$ \\
& UD ply & $d_{m a t}=\frac{\varepsilon_{r}^{f}-\varepsilon_{r, i n}^{0}}{\varepsilon_{r}^{f}-\varepsilon_{r}^{0}}\left(1-\frac{\varepsilon_{r}^{0}-\varepsilon_{r}}{\varepsilon_{r}-\varepsilon_{r, i n}^{0}}\right)$ \\
Matrix-dominated failure & Woven ply & $d_{i}=\frac{\varepsilon_{i}^{f}-\varepsilon_{i, i n}^{0}}{\varepsilon_{i}^{f}-\varepsilon_{i}^{0}}\left(1-\frac{\varepsilon_{i}^{0}-\varepsilon_{i}}{\varepsilon_{i}-\varepsilon_{i, i n}^{0}}\right)$
\end{tabular}

\section{Table 4}

Material properties for IMS60 UD carbon-fibre/epoxy and AS4 woven carbon-fibre/epoxy [34,35].

\begin{tabular}{|c|c|c|}
\hline Materials & UD lamina & 5HS lamina \\
\hline \multirow{2}{*}{ Modulus $(G P a)$} & $E_{11}=152 ; E_{22}=E_{33}=8.71$ & $E_{11}=E_{22}=65.4 ; E_{33}=8.71$ \\
\hline & $G_{12}=G_{13}=4.14 ; G_{23}=3.23$ & $G_{13}=G_{23}=3.27 ; G_{12}=3.59$ \\
\hline \multirow[t]{2}{*}{ Poisson`s ratio } & $v_{12}=v_{13}=0.3 ; v_{23}=0.35$ & $v_{13}=v_{23}=0.33 ; v_{12}=0.04$ \\
\hline & $X^{T}=1930 ; X^{C}=962$ & $X^{T}=Y^{T}=862$ \\
\hline \multirow[t]{2}{*}{ Strength $(M P a)$} & $Y^{T}=41.4 ; Y^{C}=276$ & $X^{C}=Y^{C}=689$ \\
\hline & $S_{12}=82.1$ & $S_{12}=110$ \\
\hline \multirow{3}{*}{$\begin{array}{l}\text { Intralaminar fracture toughness } \\
\left(\mathrm{kJ} / \mathrm{m}^{2}\right)\end{array}$} & $\left.G_{I c}\right|_{f t}=775 ;\left.G_{I c}\right|_{f c}=87$ & $\left.G_{I c}\right|_{f t}=201 ;\left.G_{I c}\right|_{f c}=92$ \\
\hline & $\left.G_{I c}\right|_{m t}=0.46 ;\left.G_{I c}\right|_{f c}=1.51$ & $\left.G_{I c}\right|_{m t}=0.32 ;\left.G_{I c}\right|_{m c}=2.01$ \\
\hline & $\left.G_{I I c}\right|_{m s}=1.51$ & $\left.G_{I I c}\right|_{m s}=2.01$ \\
\hline Non-linear shear coefficients & $c_{1}=66.5 ; c_{2}=3.2 ; c_{3}=62.4 ;$ & $c_{1}=77.2 ; c_{2}=3.6 ; c_{3}=65.2 ;$ \\
\hline $\begin{array}{l}\text { Interlaminar fracture toughness } \\
\left(\mathrm{kJ} / \mathrm{m}^{2}\right)\end{array}$ & $G_{I C}=0.46 ; G_{I I C}=1.51 ;$ & $G_{I C}=0.32 ; G_{I I C}=2.01 ;$ \\
\hline B-K coefficient & $\eta=1.89$ & $\eta=2.09$ \\
\hline Cohesive stiffness $\left(\mathrm{N} / \mathrm{mm}^{3}\right)$ & $8.1 \times 10^{5}$ & $6.2 \times 10^{5}$ \\
\hline
\end{tabular}




\section{Table 5}

Experimental and simulation results of crashworthiness performance.

\begin{tabular}{ccccc}
\hline & \multicolumn{2}{c}{ Bevel-trigger specimens } & \multicolumn{2}{c}{ Steeple-trigger specimens } \\
\cline { 2 - 5 } & Experiment & Simulation & Experiment & Simulation \\
\hline Crush energy $(J)$ & $17.1 \pm 2.7 \%$ & 16.4 & $11.7 \pm 1.9 \%$ & 11.8 \\
Peak-load $(k N)$ & $4.95 \pm 2.5 \%$ & 4.76 & $5.87 \pm 6.1 \%$ & 5.65 \\
SEA $(k J / k g)$ & $65.3 \pm 2.7 \%$ & 60.5 & $69.3 \pm 1.9 \%$ & 65.1 \\
\hline
\end{tabular}

